\title{
Is Ovarian Tissue Transport at Supra-zero Temperatures Compared to Body Temperature Optimal for Follicle Survival?
}

\author{
NATHALIE RAFFEL ${ }^{1}$, RALF DITTRICH ${ }^{1}$, PAUL ORLOWSKI ${ }^{1}$, HANNAH TISCHER ${ }^{1}$, STEPHAN SÖDER ${ }^{2}$, \\ RAMONA ERBER $^{3}$, INE HOFFMANN ${ }^{1}$, MATTHIAS W. BECKMANN ${ }^{1}$ and LAURA LOTZ ${ }^{1}$ \\ ${ }^{1}$ Department of Obstetrics and Gynecology, Erlangen University Hospital, \\ Friedrich-Alexander University of Erlangen-Nürnberg, Erlangen, Germany; \\ ${ }^{2}$ Institute of Pathology, Coburg Hospital, Coburg, Germany; \\ ${ }^{3}$ Institute of Pathology, Erlangen University Hospital, \\ Friedrich-Alexander University of Erlangen-Nürnberg, Erlangen, Germany
}

\begin{abstract}
Background/Aim: Transportation of ovarian cortex prior to freezing is used clinically; however, basic investigations of ovarian storage are limited and the question remains what temperature is optimal for transport over long distances and time periods. The aim of this study was to evaluate the rate of follicular loss over various time periods under two different temperatures and assess whether ovarian follicle viability is affected following cryopreservation and thawing subsequent to the transportation of ovarian tissue. Materials and Methods: Pig ovaries were transported at $4^{\circ} \mathrm{C}$ $(n=10)$ or at $38^{\circ} \mathrm{C}(n=10)$ prior to cryopreservation. At 0,4 , 12 and 24 h tissues were fixed for histological examination and a LIVE/DEAD Assay. At the same time-points ovarian tissues were cryopreserved and analysed after thawing. Results: Histological evaluation and LIVE/DEAD Assay of freshly transported ovarian tissue showed significantly better follicle survival at $4^{\circ} \mathrm{C}$ during transportation duration. In cryopreserved ovarian tissues the LIVE/DEAD Assay showed a significant difference in the number of intact and dead follicles at $24 \mathrm{~h}$ in favor of $4^{\circ} \mathrm{C}(p<0.05)$. Conclusion: Ovarian tissue transportation should be kept at a minimum to prevent potential damage.
\end{abstract}

Chemotherapy and radiotherapy during treatment of malignant diseases often result in the loss of gonadal function, and the

This article is freely accessible online.

Correspondence to: Prof. R. Dittrich, Ph.D., Department of Obstetrics and Gynecology, Erlangen University Hospital, Universitätsstrasse 21-23, D-91054 Erlangen, Germany. Tel: +49 91318533553. Fax: +4991318533552. E-mail: ralf.dittrich@uk-erlangen.de

Key Words: Ovarian tissue transportation, fertility preservation, cryopreservation, ovarian storage, ovarian follicle viability, follicle loss. resulting infertility is a problem for a large number of patients (1-3). Cryopreservation of ovarian tissue is an effective technique to preserve fertility in patients undergoing gonadotoxic therapies $(4,5)$. To date about 130 live births worldwide resulted from ovarian tissue cryopreservation and autotransplantation in recovering cancer patients. The pregnancy rate with the use of this technique is estimated about 25-30\% and overall, the pregnancy rate with the use of cryopreservation of ovarian tissue seems to be increasing (6-8).

However, cryopreservation of human ovarian cortex is a complex procedure that requires experience and validation of the technique (9). The ability to perform ovarian tissue cryopreservation requires trained staff, specialized equipment, designated space and time to prepare the ovarian cortex and freeze it using specified protocols $(10,11)$. Due to these factors, the number of clinical hospitals that offer ovarian tissue cryopreservation for fertility preservation remains low. Therefore, cryobanking with transportation of ovarian cortex before cryopreservation is clinically used to make the option accessible to patients in regions in which a fertility centre with the required facilities and skills for cryopreservation is not available. It is a useful option for patients with serious illnesses in whom the start of treatment cannot be postponed and who therefore may not wish to move from one centre to another or may not be able to. In Germany and Denmark, ovarian tissue is harvested at regional hospitals, because laparoscopic retrieval of fragments of human cortex is an established operation that can be comprehensively offered; those fragments are sent to centres that can perform ovarian tissue cryopreservation $(12,13)$.

Although live births have been reported after ovarian transport overnight on ice before freezing ovarian tissue (13), basic investigations of ovarian storage are limited in numbers; little is known on the optimal transportation temperature, optimal media composition and maximally tolerable transportation duration as well as the interaction of 
all these factors. The question remains what temperature is optimal for transportation over long distances and time periods. Optimization of the initial transportation conditions of the ovarian tissue prior to cryopreservation is necessary to allow for ovarian tissue cryopreservation to be more widely employed for the preservation of fertility.

Therefore, the present study was performed to evaluate the rate of follicle loss over various time periods under two different temperatures and assess whether ovarian follicle viability is affected following cryopreservation and thawing subsequent to the transportation of ovarian tissue.

\section{Materials and Methods}

Ovarian tissue harvesting and work programme. The use of human ovaries for studies is scarce when compared to animal models due to ethical barriers and limited availability of material for research. Therefore, to address these aims, pig ovaries were utilized because the pig has been demonstrated to be an appropriate model for human reproductive biology $(14,15)$ and samples are easily obtained and plentiful. The normal body temperature of a pig is approximately $38-40^{\circ} \mathrm{C}$.

Ovaries were harvested from 10 pigs aged between 6 months 1 year. The pig ovary is similar in size to the human $(3-4 \mathrm{~cm}$ long and 2-3 cm wide). Ovaries were sectioned within petri dishes with a micrometer etched on the bottom to facilitate the measurement of appropriate sized section $(6 \times 4 \times 1 \mathrm{~mm})$. The allocation of a large number of cortical strips from each ovary to both treatment groups, and the consistency of the sampling method throughout the study, ensured an accurate reflection of follicle activity.

The cortical strips were rinsed by three washes in saline solution $(0.9 \% \mathrm{NaCl})$ at room temperature $\left(22^{\circ} \mathrm{C}\right)$, then placed in PBS medium and evenly divided between transport at $4^{\circ} \mathrm{C}$ or transport at $38^{\circ} \mathrm{C}$ (pig body temperature). Transport at $4^{\circ} \mathrm{C}$ samples were held in a special insulated transportation box (Z100037054; delta T Ltd., UP GmbH, Cottbus, Germany) for the duration of each experiment. Transport at $38^{\circ} \mathrm{C}$ samples were kept in an incubator (Heracell 150i, Thermo Scientific).

Samples from each treatment temperature were removed for analysis of tissue quality at various time points ( $0 \mathrm{~h}$ (control), $4 \mathrm{~h}, 12 \mathrm{~h}$ and $24 \mathrm{~h}$ ) to provide insight on the rate of follicle loss over time and at different temperatures (Figure 1). A portion of the samples collected from the ovaries were allocated for cryopreservation at the various time points for each treatment. The ovarian tissue was frozen in accordance with a slow-freezing protocol. The detailed protocol for freezing and thawing of the ovarian cortex has been previously described $(13,16)$. These cryopreserved samples were thawed after a certain period (minimum of one week) and undergo the same analyses as the fresh samples from the same cohort (Figure 1).

\section{Analysis of tissue quality.}

1. Histological evaluation. Ovarian tissue pieces from each group were fixed in $4 \%$ formaldehyde, embedded in paraffin, serially sectioned ( 5 $\mu \mathrm{m})$ and mounted onto microscope slides (Superfrost Ultra; Menzel, Braunschweig, Germany). The slides were dried overnight at $42^{\circ} \mathrm{C}$ and stained with haematoxylin (Waldeck, Münster, Germany) and eosin (Sigma Aldrich, Chemie GmbH, Munich, Germany). The prepared serial sections were used to determine follicle count throughout the tissue. The number of viable and atretic/degenerated/degenerating follicles was counted; as it is not always possible to clearly distinguish between atretic, degenerating or already degenerated follicles, all of them are termed "degenerated" in the following. Follicles containing an oocyte whose nucleolus can be clearly defined was scored for follicle classification and counted. Classification of follicles based on their morphological appearance was as follows: primordial follicles: oocyte surrounded by a single layer of flattened granulosa cells; primary stage: oocyte surrounded by one layer of cuboidal granulosa cells; preantral follicles: the granulosa cells are cuboidal with a minimum of two cell layers around the oocyte. Follicles were classified as normal containing an intact oocyte and well-organized granulosa cells without pycnotic nuclei; degenerated ones when containing a shrunken oocyte with somewhat pycnotic nuclei, disorganized granulosa cells and low cellular density. Serial sectioning is an established method with which to determine the number of follicles in a tissue area.

2. Investigation of apoptosis-LIVE/DEAD viability assay. A fluorescence stain was used to estimate the number of follicles that had survived in vitro. The LIVE/DEAD viability/cytotoxicity assay kit (L-3224, Molecular Probes ${ }^{\circledR}$, Leiden, the Netherlands) provides a two-color fluorescence cell viability assay that is based on simultaneous determination of alive and dead cells. The method has been described elsewhere (17). In brief, the tissue was digested in PBS medium supplemented with $1 \mathrm{mg} / \mathrm{ml}$ collagenase (Collagenase Type IV, SigmaAldrich $^{\circledR}$, Steinheim, Germany) and incubated at $37^{\circ} \mathrm{C}$ for $2 \mathrm{~h}$. The samples were stained according to the assay instructions and were subsequently examined under a Zeiss fluorescence microscope (IM $35^{\circledR}$, Zeiss, Oberkochen, Germany). The follicles were considered dead, only when both the oocyte and all the granulosa cells were dead $(17,18)$.

Ethics approval. Ethical approval by the Animal Experiments committee for the use of pig ovaries (garbage of the slaughterhouse) is not necessary because no additional animals were killed. The use of the material of the slaughterhouse was approved by the Veterinary Office of the city of Erlangen (file reference: DE09562003821).

Statistical analysis. The SPSS program was used for data evaluation (IBM SPSS Statistics, NY, USA). Levene's test of homogeneity of variances $(\alpha=0.01)$ and the Shapiro-Wilk test of normality $(\alpha=0.01)$ were performed to select the appropriate statistical tests. Nominal data were expressed as means plus or minus standard deviation and compared using Student's $t$-test or the Mann-Whitney $U$-test. If more than two experimental groups were being compared, analysis of variance (ANOVA) was performed with the Tamhane post-hoc test for comparison in case of statistical significance. A $p$-value of 0.05 was considered statistically significant.

\section{Results}

Histological evaluation. Histological evaluation showed an intact morphology in fresh ovarian tissue pieces at $4^{\circ} \mathrm{C}$ and at $38^{\circ} \mathrm{C}$ over the transportation time (Figure 2). At $4^{\circ} \mathrm{C}$ primordial and primary follicles were significantly reduced after $12 \mathrm{~h}$ $(p<0.05)$ and preantral follicles after $24 \mathrm{~h}(p<0.05)$ compared to time point $0 \mathrm{~h}$ (control). At $38^{\circ} \mathrm{C}$ the numbers of primordial and primary follicles were already reduced after $4 \mathrm{~h}$ and preantral follicles after $12 \mathrm{~h}$ compared to $0 \mathrm{~h}(p<0.05)$. 


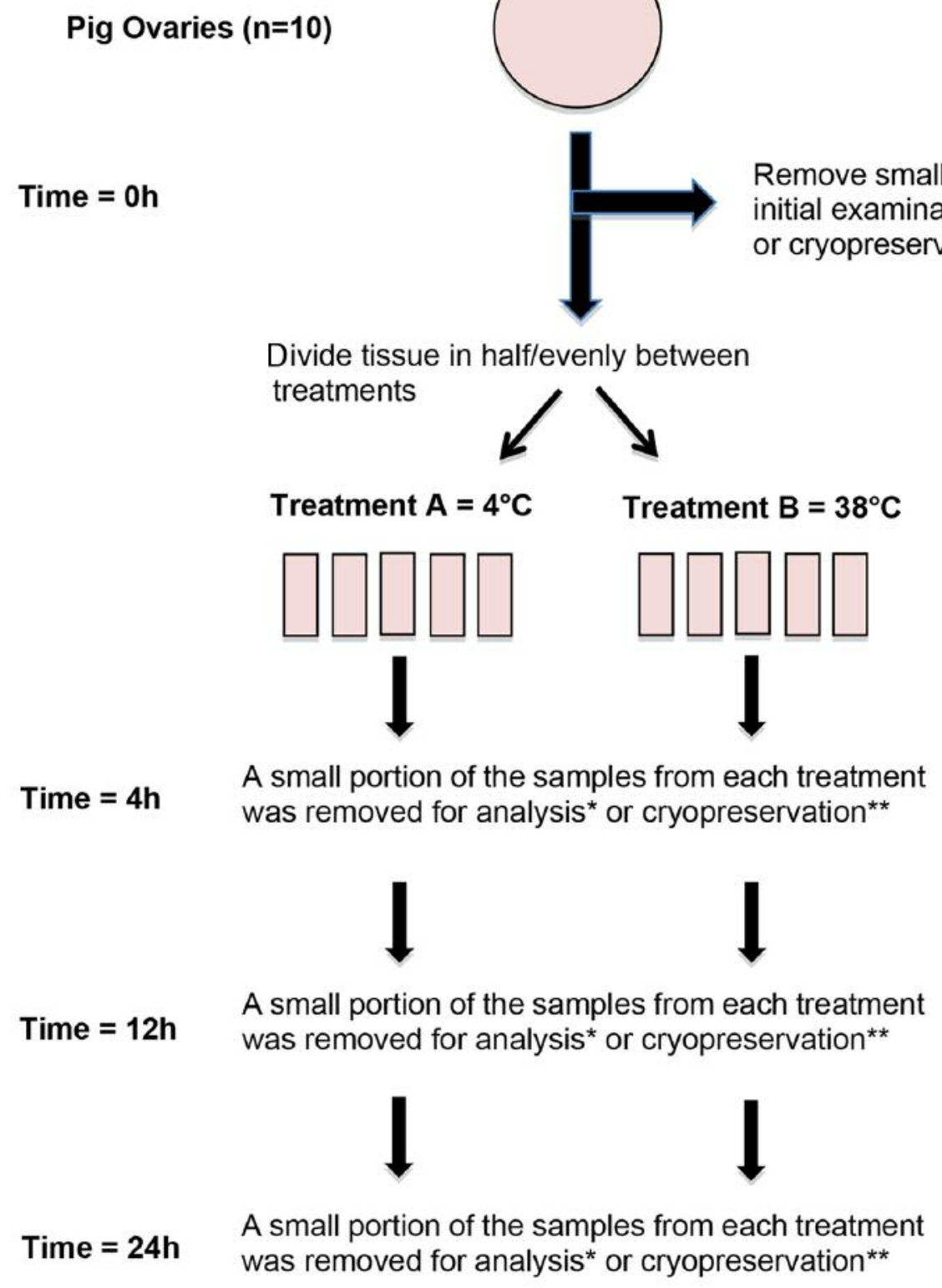

Figure 1. Experimental design. *Analysis of tissue quality included histology for general anatomical structure (standard haematoxylin and eosin staining) and LIVE/DEAD Viability Assay. ${ }^{*}$ Cryopreservation of representative ovarian tissue strips from each time period and treatment was performed and later analyzed using the same techniques mentioned for fresh tissue.

Comparison between both storage groups revealed a significant difference in intact primary and preantral follicles in favor of $4^{\circ} \mathrm{C}$ over transportation duration $(p<0.05)$. The mean number of degenerated follicles increased over transportation time and was in both groups significant increased after $24 \mathrm{~h}$ of transportation compared to time-point $0 \mathrm{~h}(p<0.05)$. At $38^{\circ} \mathrm{C}$ after $24 \mathrm{~h}$ of transportation significant more degenerated follicles were present compared to $4^{\circ} \mathrm{C}(p<0.05)$ (Figure 3).
In the cryopreserved ovarian tissue, the mean number of morphologically viable primary and preantral follicles was reduced in both storage groups compared with fresh ovarian tissue $(p<0.05)$, whereas no difference could be detected regarding primordial follicles. There were no marked histological differences regarding viable primordial follicles between $4^{\circ} \mathrm{C}$ and $38^{\circ} \mathrm{C}$ over transportation time. At $4^{\circ} \mathrm{C}$ primordial, primary and preantral follicles remained 

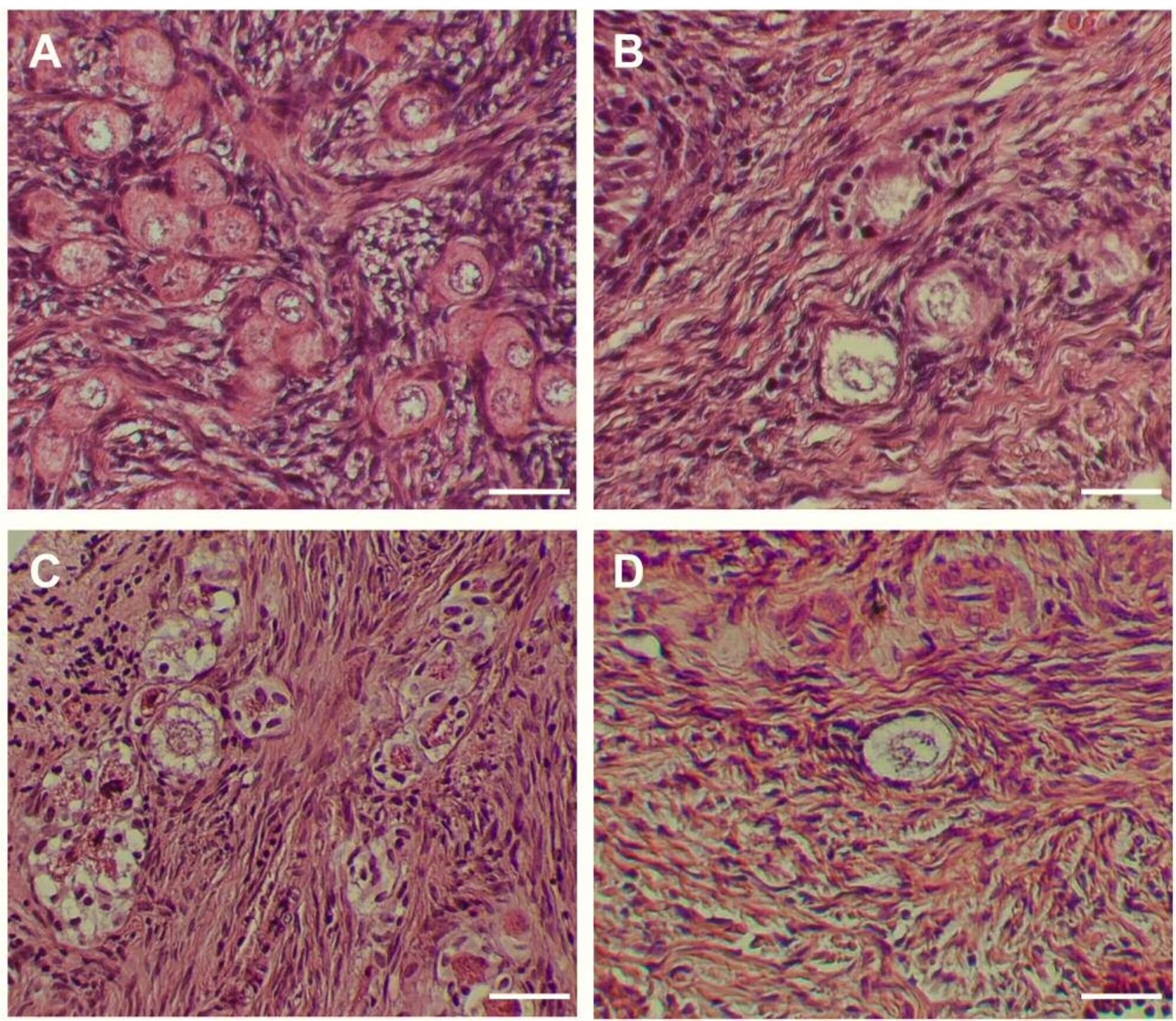

Figure 2. Illustrative images of primordial follicles enclosed in ovarian tissue stored at $4^{\circ} \mathrm{C}$ and $38^{\circ} \mathrm{C} . H \& E$ staining of ovarian tissue transported (A) at $4^{\circ} \mathrm{C}$ for $4 \mathrm{~h}\left(\right.$ B) at $4^{\circ} \mathrm{C}$ for $24 \mathrm{~h} .(\mathrm{C})$ at $38^{\circ} \mathrm{C}$ for $4 \mathrm{~h}$ and (D) at $38^{\circ} \mathrm{C}$ for $24 \mathrm{~h}$. Scale bar $=50 \mu \mathrm{m}$.

approximately constant over time. At $38^{\circ} \mathrm{C}$ primary and preantral follicles were reduced after $24 \mathrm{~h}$ and the mean number of degenerated follicles increased significant after $4 \mathrm{~h}$ of transportation $(p<0.05)$ (Figure 3$)$.

Live/dead viability assay. The results of fluorescence staining of the ovarian tissue pieces for $4^{\circ} \mathrm{C}$ and $38^{\circ} \mathrm{C}$ over the transportation time are given in Table I. Intact follicles declined, and the number of dead follicles increased steadily in both storage groups over the transport time in fresh transported ovarian tissue. At $4^{\circ} \mathrm{C}$ transport temperature, the number of intact cells significantly declined, and the number of dead cells increased after $24 \mathrm{~h}$ of transportation $(p<0.05)$. Whereas at $38^{\circ} \mathrm{C}$, the number of intact follicles was already significantly reduced after $12 \mathrm{~h}$ and the number of dead follicles significantly increased $(p<0.05)$. Comparison between both storage groups revealed a significant difference with more survival of follicles at $4^{\circ} \mathrm{C}$ after $12 \mathrm{~h}$ of transportation $(p<0.05)$.

Regarding the fresh ovarian tissue at the same incubation time, the results showed less intact follicles and more dead follicles in the cryopreserved ovarian tissue $(p<0.05)$. There was a reduction of percentage of live follicles with the increase of incubation time in both groups after $12 \mathrm{~h}$ of transportation. Comparisons between $4^{\circ} \mathrm{C}$ and $38^{\circ} \mathrm{C}$ at the same incubation time in the cryopreservated ovarian tissue showed a significant difference in the number of intact and dead follicles at $24 \mathrm{~h}$ in favor for $4^{\circ} \mathrm{C}(p<0.05)$. 
A
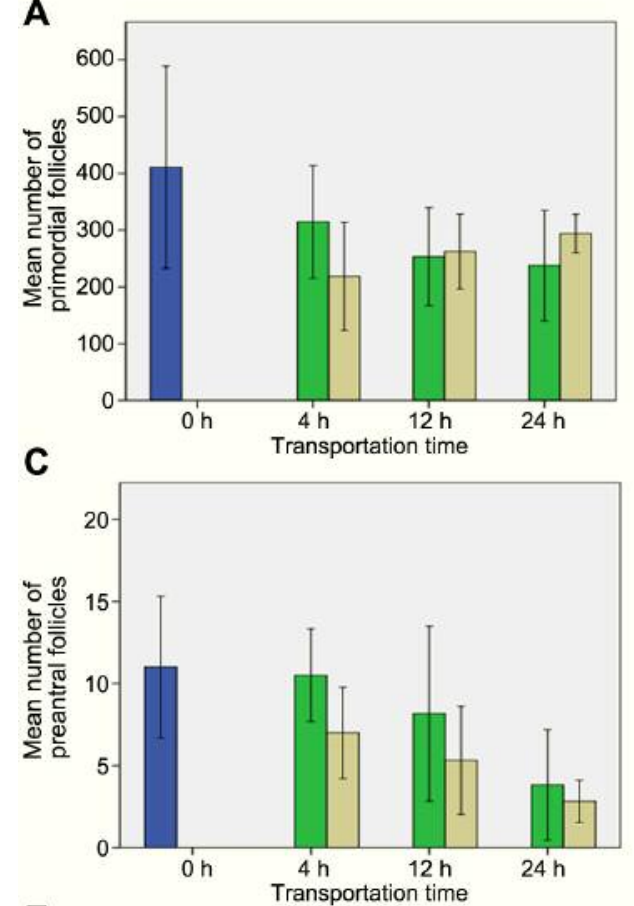

\section{E}
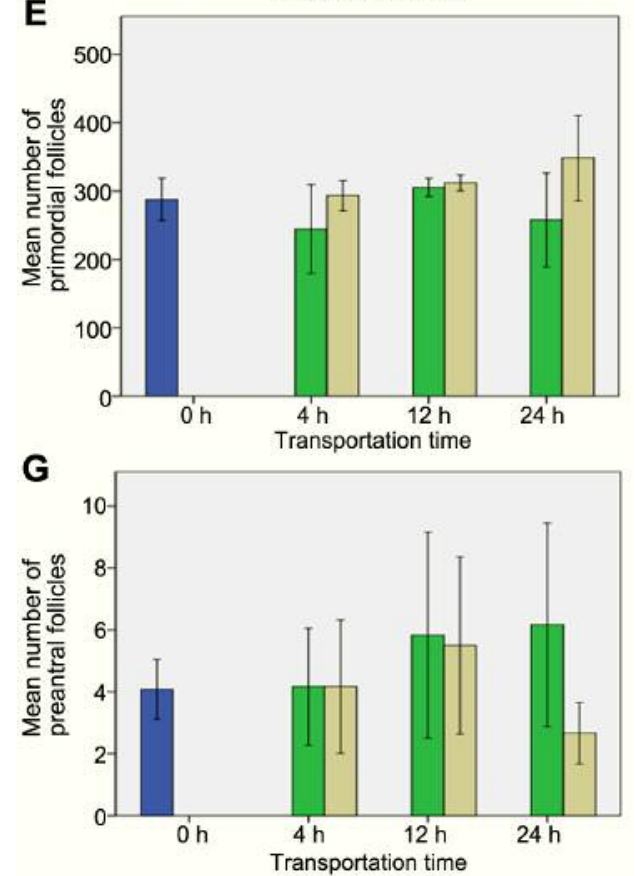
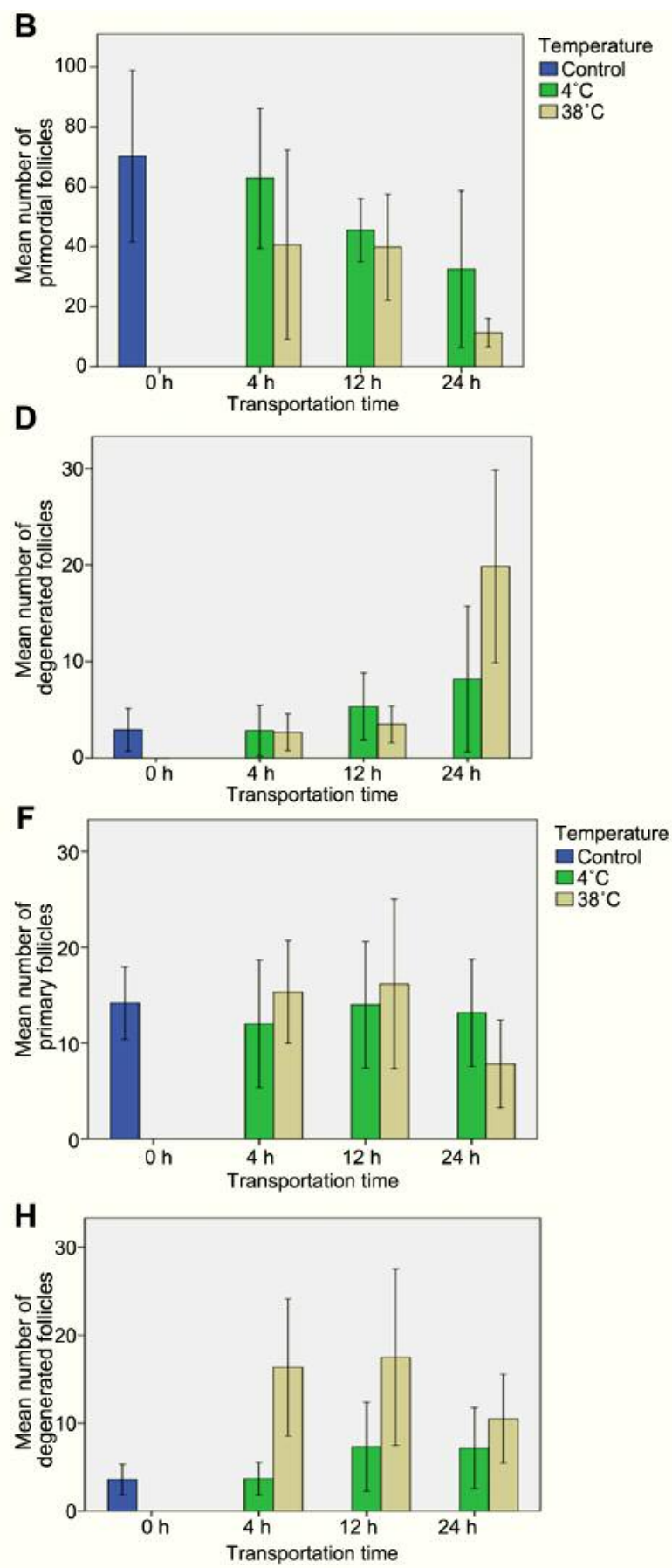

Figure 3. Mean numbers of follicles in ovarian tissue after transportation at $4^{\circ} \mathrm{C}$ and $38^{\circ} \mathrm{C}$. Mean number ( \pm standard error of the mean $(S E M)$ ) of primordial $(A)$, primary $(B)$ preantral $(C)$ and degenerated $(D)$ follicles in fresh ovarian tissue and primordial $(E)$, primary $(F)$ preantral $(G)$ and degenerated $(H)$ in cryopreserved ovarian tissue after different durations of transportation at $4^{\circ} \mathrm{C}$ and $38^{\circ} \mathrm{C} .{ }^{a}$ Differs significantly from transportation time 0 hours $(h) /$ control in the same treatment group $(p<0.05) .{ }^{b}$ Differs significantly between $4^{\circ} \mathrm{C}$ and $38^{\circ} \mathrm{C}$ at the same transportation time $(p<0.05)$.

\section{Discussion}

In the present study, our data provide evidence that interim storage at $4^{\circ} \mathrm{C}$ could result in better follicle viability than physiological body temperature. For ovarian tissue, it has been indicated that precooled transport of the tissue is possible for up to $24 \mathrm{~h}$ (19). Hornick et al. (20) transported primate ovarian tissue at $4^{\circ} \mathrm{C}$ for up to $24 \mathrm{~h}$. Follicle health 
Table I. Clinicopathological characteristics of patients.

\begin{tabular}{|c|c|c|c|c|c|}
\hline & & \multicolumn{2}{|c|}{ Fresh ovarian tissue } & \multicolumn{2}{|c|}{ Cryopreserved ovarian tissue } \\
\hline & & Live $\%$ & Death \% & Live $\%$ & Death \% \\
\hline & Oh & $81.80 \% \pm 3.89 \%$ & $18.20 \% \pm 3.89 \%$ & $67.86 \% \pm 11.26 \%$ & $32.14 \% \pm 11.26 \%$ \\
\hline \multirow[t]{3}{*}{$4^{\circ} \mathrm{C}$} & $4 \mathrm{~h}$ & $81.09 \% \pm 6.78 \%$ & $18.91 \% \pm 6.87 \%$ & $72.01 \% \pm 12.16 \%$ & $27.99 \% \pm 12.16 \%$ \\
\hline & $12 \mathrm{~h}$ & $78.42 \% \pm 9.86 \%$ & $21.58 \% \pm 9.86 \%$ & $51.12 \% \pm 22.82 \%^{a}$ & $48.88 \% \pm 22.82 \% \mathrm{a}$ \\
\hline & $24 \mathrm{~h}$ & $68.52 \% \pm 8.37 \%$ a & $31.48 \% \pm 8.37 \% \mathrm{a}$ & $57.50 \% \pm 11.55 \% \mathrm{a}^{\mathrm{a}}$ & $42.50 \% \pm 11.55 \% \mathrm{a}$ \\
\hline \multirow[t]{3}{*}{$38^{\circ} \mathrm{C}$} & $4 \mathrm{~h}$ & $67.99 \% \pm 25.3 \%$ & $32.01 \% \pm 25.31 \%$ & $71.73 \% \pm 30.23 \%$ & $28.28 \% \pm 30.23 \%$ \\
\hline & $12 \mathrm{~h}$ & $57.79 \% \pm 11.6 \% \mathrm{ab}$ & $42.21 \% \pm 11.62 \% \mathrm{a} \mathrm{b}^{2}$ & $58.02 \% \pm 24.50 \% \mathrm{a}$ & $41.98 \% \pm 24.50 \%$ a \\
\hline & $24 \mathrm{~h}$ & $27.76 \% \pm 23.5 \% \mathrm{ab}$ & $72.24 \% \pm 23.55 \%$ a b & $28.00 \% \pm 20.85 \%$ a b & $72.00 \% \pm 20.85 \% \mathrm{ab}$ \\
\hline
\end{tabular}

Percentage (mean \pm standard error of the mean (SEM)) of live and dead follicles in ovarian tissue pieces for $4^{\circ} \mathrm{C}$ and $38^{\circ} \mathrm{C}$ over the transportation time prior and after freezing the ovarian tissue. ${ }^{a}$ Differs significantly from transportation time 0 hours $(\mathrm{h})$ in the same treatment group $(p<0.05)$. bDiffers significantly between $4^{\circ} \mathrm{C}$ and $38^{\circ} \mathrm{C}$ at the same time period of transportation $(p<0.05)$.

in the transported ovarian tissue was maintained compared to freshly fixed controls and there was no difference in the number of apoptotic cells. Additionally, follicles isolated from these transported tissues survived and grew in an encapsulated in vitro follicle growth system that recapitulates oogenesis and folliculogenesis, demonstrating the functionality of these cells post-transport (20). Kamoshita et al. (21) stored mice ovarian tissue at $4^{\circ} \mathrm{C}$ for up to $24 \mathrm{~h}$ and the histological morphology of the tissue and the number of mature gametes that could be fertilized post-orthotopic transplantation were not significantly affected. However, cold storage significantly reduced the incidence of implantation and live offspring. In a study with equine ovarian tissue the highest percentage of viable follicles was found when the tissue was transported at $4^{\circ} \mathrm{C}$ for $4 \mathrm{~h}(22)$.

These results are in accordance with the present findings. Increasing the time and temperature of tissue transport significantly reduced the percentage of morphologically normal follicles. At $38^{\circ} \mathrm{C}$ primary and preantral follicles were already declined after $4 \mathrm{~h}$. But also, at $4^{\circ} \mathrm{C}$ significant negative effects occurred within transportation period. The follicle reserve declined significantly after $12 \mathrm{~h}$ of transportation in fresh ovarian tissue. Hypothermia to approximately $4^{\circ} \mathrm{C}$, widely used for organ transport due to retarded metabolism and decreased biological processes, can also induce damage due to chilling effects, such as vasoconstriction, dehydration as well as extra- and intracellular ice crystal formation (23).

Some studies have demonstrated better tissue survival at body temperature, albeit over relatively short holding time periods $(24,25)$. In a study with ovine ovarian tissue, it was shown that ovarian tissue was successfully preserved in supplemented medium $\left(\mathrm{MEM}^{+}\right)$at a temperature close to physiological values $\left(35^{\circ} \mathrm{C}\right)$ for up to $6 \mathrm{~h}$ without affecting apoptosis in the ovarian follicles and their ability to develop in vitro (26). Weissmann et al. (24) transplanted fresh ovarian tissue into SCID mice after transportation on ice or at $37^{\circ} \mathrm{C}$ within $2 \mathrm{~h}$. Follicular survival and development were significantly increased when warm tissue transport medium was used compared to cold transport (26 of 32 [81.3\%] vs. 2 of 7 [28.6\%], respectively; $p<0.05)$. They suggest that oocytes in primordial and primary follicles have sensitivity to chilling effects similar to the known chilling sensitivity of mature oocytes and follicles (24). However, the time span for transportation was only $2 \mathrm{~h}$ and no cryopreservation was performed afterwards.

Taken the effects of freezing/thawing into consideration in this study, histological examination showed no differences regarding primordial follicles between $4^{\circ} \mathrm{C}$ and $38^{\circ} \mathrm{C}$ over transportation time. At $38^{\circ} \mathrm{C}$, however, primary and preantral follicles were reduced after $24 \mathrm{~h}$. Primary and preantral follicles are less susceptible to degeneration than primordial follicles when stored. Primordial follicles are quiescent, whereas primary follicles are already activated and in early growth. Cells undergoing such transformations may be more sensitive to environmental factors.

Although histological analysis of follicles remains the most classical method, additional measurements such as live-dead assay are helpful in reliably evaluating the viability of follicles. The LIVE/DEAD Viability Assay is a reproducible predictive method to study the survival of ovarian tissue and it has been shown that the method is comparable with in vivo maturation to predict the developmental potential of the ovarian tissue $(17,27)$. The results of the live dead viability assay also demonstrated that intact follicles decreased during prolonged storage, while apoptotic follicles increased. The comparison between both storage groups revealed a significantly better survival of the follicles at $4^{\circ} \mathrm{C}$ over transportation time before and after freezing the ovarian tissue.

The sensitivity to temperature storage differs among mammalian species and therefore the possibility of 
differences between humans and pig cannot be excluded. Nevertheless, the study was performed to assess the prevention of the accumulation of damage in follicles; therefore, we suspect that it should be applicable in clinical work. In general, studies with human ovarian tissue are very rare due to ethical barriers and the limited availability of material for research; therefore, only few studies for human ovarian tissue transport have been published. In one study, ovarian cortical tissue from 9 individuals was transported at $4^{\circ} \mathrm{C}$ between 15.8 and $21.9 \mathrm{~h}$ and cell quality, as well as morphology were compared in histological and TUNEL analyses to pre-transport control tissue from the same individual (28). In five cases, the transported tissue was histologically similar to the freshly fixed control tissue, and TUNEL analysis demonstrated a similar percentage of apoptotic cells. In four samples, significantly more TUNELpositive cells were observed in the post-transport tissue than in the corresponding fresh tissue. These TUNEL-positive cells, however, were primarily constrained to the edge of the tissue. (28). Isachenko et al. (29) also showed that storage of ovarian tissue at supra-zero temperatures for up to $26 \mathrm{~h}$ did not compromise the in vitro development of follicles during subsequent culture of intact tissue pieces. Storage of human ovarian cortex at $5^{\circ} \mathrm{C}$ for $24 \mathrm{~h}$ prior to cryopreservation even increased the viability of the follicles, as assessed by immunohistochemical analysis. In contrast, Klocke et al. (30) showed that storage at supra-zero conditions has detrimental effects on the human ovarian cortex. In the storage medium of fresh ovarian tissue from 12 women stored at $4^{\circ} \mathrm{C}$ for 24 or $48 \mathrm{~h}$ before vitrification, increasing amounts of malondialdehyde (MDA), a marker of oxidative stress, were detectable. The post-warming proportion of follicles with high morphological quality decreased with longer storage, while the proportion of apoptotic follicles increased, although these effects did not reach statistical significance.

In this context, live births after transplantation of ovarian tissue, transported before freezing, appear to be the strongest support for the efficacy of ovarian tissue transport (19). In Germany the first live birth after transplantation of ovarian tissue was achieved in a patient, where the ovarian tissue has been transported at $5^{\circ} \mathrm{C}$ to $8^{\circ} \mathrm{C}$ for $20 \mathrm{~h}$ prior freezing (31). Ven et al. (32) reported that fifty-three percent of the pregnancies $(n=10 / 19)$ were achieved after transportation of the ovarian tissue overnight. This data shows that sufficient follicles survive the procedure of overnight transportation for a successful pregnancy result. However, a comparison between transplantations with and without prolonged transport duration of the ovarian tissue has not yet been done and is urgently needed.

In order to determine which transport conditions are more conductive for follicle survival and health, the size of the ovarian tissue and the transport medium play an important role besides temperature and duration of transport. In the present study the ovarian tissue was cut into fragments of approximately $6 \times 4 \times 1 \mathrm{~mm}$ before transportation. Studies have shown a large variation in fragment size from whole ovary (21) to very small fragments (<1 mm thickness) (33) submitted to transport, cryopreservation and/or transplantation; consequently a large variation in follicle survival has been noticed (34). Moreover, studies have evaluated different types of medium for transport and storage of ovarian fragments and have shown relevant results regarding the preservation of preantral follicle morphology (8). In this study the ovarian tissue was transported in PBSMedium. Gomes et al. (35) transferred ovarian tissue in phosphate-buffered saline (PBS) or in Minimum Essential Medium (MEM) during transportation and handling at $4{ }^{\circ} \mathrm{C}$, $20^{\circ} \mathrm{C}$ and $39^{\circ} \mathrm{C}$ for 4,12 , or $24 \mathrm{~h}$. After the incubation periods, the tissue pieces were fixed in Bouin's solution for $24 \mathrm{~h}$ and then submitted to standard histologic analysis. At $4^{\circ} \mathrm{C}$ for $4 \mathrm{~h}$, considering primordial and developing follicles, PBS had a higher $(p<0.05)$ rate $(98.9 \%)$ of morphologically normal follicles than MEM, 48.7\% . (35). Furthermore, it has been shown that addition of anti-apoptotic agents in the transport, processing, and cryopreservation media could improve the quality of primordial follicles post-thaw as assessed by culture and histological evaluation (36). These could be new starting points for optimizing the transport of ovarian tissue.

In conclusion, transportation of ovarian cortex prior to cryopreservation opens possibilities for patients in regions or countries where a fertility center with the required facilities and skills is not available, leaving the patient independent of local expertise. However, the transportation durations should be kept at a minimum to prevent potential damage. In individual cases, where ovarian tissue cryopreservation could not be offered, prolonged transportation at $4^{\circ} \mathrm{C}$ could be performed, as the follicle loss is modest. Additionally, the results showed that if the temperature accidentally increases during transportation the tissue is not destroyed. Since ovarian cryopreservation and transportation is increasingly used, further studies are needed and guidelines for optimum storage methods need to be developed.

\section{Conflicts of Interest}

The Authors declare that they have no conflicts of interests.

\section{Authors' Contributions}

N.R., L.L. R.D. designed the study, analyzed the data, and wrote the manuscript. N.R., P.O., H.T., S.S., R.E. and I.H. collected the data. N.R., L.L., P.O., H.T. carried out the analyses. S.S. and R.E carries out the histological work. M.W.B., R.D. and L.L. supervised the study. All Authors read and approved the final manuscript. 


\section{Acknowledgements}

Parts of the present work were performed by N. Raffel in partial fulfillment of the requirements of the Friedrich-Alexander University of Erlangen-Nürnberg for obtaining the degree, Dr. rer. biol. hum.". Some of the data included also form part of the doctoral thesis of P. Orlowski as well as H. Tischer; for the M.D. degree at Friedrich Alexander University, Erlangen-Nürnberg, Germany. The research was supported by grants from the Wilhelm Sander-Stiftung (reference no. 2008.086.1 and 2012.127.1), Munich, Germany.

\section{References}

1 Henes M, Neis F, Kramer B, Walter C, Brucker S, Von Wolff M, Rothmund R, Lawrenz B and Rall K: Possibilities of fertility preservation in young patients with ovarian cancer. Anticancer Res 34(7): 3851-3854, 2014. PMID: 24982413.

2 Mueller A, Maltaris T, Dimmler A, Hoffmann I, Beckmann MW and Dittrich R: Development of sex cord stromal tumors after heterotopic transplantation of cryopreserved ovarian tissue in rats. Anticancer Res 25(6b): 4107-4111, 2005. PMID: 16309204

3 Maltaris T, Beckmann MW and Dittrich R: Review. Fertility preservation for young female cancer patients. In Vivo 23(1): 123-130, 2009. PMID:19368136.

4 Meirow D, Ra'anani H, Shapira M, Brenghausen M, Derech Chaim S, Aviel-Ronen S, Amariglio N, Schiff E, Orvieto R and Dor J: Transplantations of frozen-thawed ovarian tissue demonstrate high reproductive performance and the need to revise restrictive criteria. Fertil Steril 106(2): 467-474, 2016. PMID: 27181924. DOI: 10.1016/j.fertnstert.2016.04.031

5 Salama M and Mallmann P: Emergency fertility preservation for female patients with cancer: Clinical perspectives. Anticancer Res 35(6): 3117-3127, 2015. PMID: 26026071.

6 Gellert SE, Pors SE, Kristensen SG, Bay-Bjorn AM, Ernst E and Yding Andersen C: Transplantation of frozen-thawed ovarian tissue: An update on worldwide activity published in peerreviewed papers and on the danish cohort. J Assist Reprod Genet 35(4): 561-570, 2018. PMID: 29497953. DOI: 10.1007/s10815$018-1144-2$

7 Donnez J, Manavella DD and Dolmans MM: Techniques for ovarian tissue transplantation and results. Minerva Ginecol 70(4): 424-431, 2018. PMID: 29644328. DOI: 10.23736/s00264784.18.04228-4

8 Jensen AK, Macklon KT, Fedder J, Ernst E, Humaidan P and Andersen CY: 86 successful births and 9 ongoing pregnancies worldwide in women transplanted with frozen-thawed ovarian tissue: Focus on birth and perinatal outcome in 40 of these children. J Assist Reprod Genet 34(3): 325-336, 2017. PMID: 28028773. DOI: $10.1007 / \mathrm{s} 10815-016-0843-9$

9 Kyono K, Hashimoto T, Toya M, Koizumi M, Sasaki C, Shibasaki S, Aono N, Nakamura Y, Obata R, Okuyama N, Ogura $\mathrm{Y}$ and Igarashi H: A transportation network for human ovarian tissue is indispensable to success for fertility preservation. J Assist Reprod Genet 34(11): 1469-1474, 2017. PMID: 28866830. DOI: 10.1007/s10815-017-1022-3

10 Backhus LE, Kondapalli LA, Chang RJ, Coutifaris C, Kazer R and Woodruff TK: Oncofertility consortium consensus statement: Guidelines for ovarian tissue cryopreservation. Cancer Treat Res
138: 235-239, 2007. PMID: 18080669. DOI: 10.1007/978-0-38772293-1_17

11 Ovarian tissue cryopreservation: A committee opinion. Fertil Steril 101(5): 1237-1243, 2014. PMID: 24684955. DOI: 10.1016/j.fertnstert.2014.02.052

12 Jensen AK, Kristensen SG, Macklon KT, Jeppesen JV, Fedder J, Ernst E and Andersen CY: Outcomes of transplantations of cryopreserved ovarian tissue to 41 women in denmark. Hum Reprod 30(12): 2838-2845, 2015. PMID: 26443605. DOI: 10.1093/humrep/dev230

13 Dittrich R, Hackl J, Lotz L, Hoffmann I and Beckmann MW: Pregnancies and live births after 20 transplantations of cryopreserved ovarian tissue in a single center. Fertil Steril 103(2): 462-468, 2015. PMID: 25487750. DOI: 10.1016/ j.fertnstert.2014.10.045

14 Borges EN, Silva RC, Futino DO, Rocha-Junior CM, Amorim CA, Bao SN and Lucci CM: Cryopreservation of swine ovarian tissue: Effect of different cryoprotectants on the structural preservation of preantral follicle oocytes. Cryobiology 59(2): 195-200, 2009. PMID: 19616533. DOI: 10.1016/j.cryobiol. 2009.07.003

15 Nichols-Burns SM, Lotz L, Schneider H, Adamek E, Daniel C, Stief A, Grigo C, Klump D, Hoffmann I, Beckmann MW and Dittrich R: Preliminary observations on whole-ovary xenotransplantation as an experimental model for fertility preservation. Reprod Biomed Online 29(5): 621-626, 2014. PMID: 25246124. DOI: 10.1016/j.rbmo.2014.07.017

16 Dittrich R and Maltaris T: A simple freezing protocol for the use of an open freezing system for cryopreservation of ovarian tissue. Cryobiology 52(1): 166, 2006. PMID: 16403490. DOI: 10.1016/j.cryobiol.2005.11.005

17 Maltaris T, Kaya H, Hoffmann I, Mueller A, Beckmann MW and Dittrich R: Comparison of xenografting in scid mice and live/dead assay as a predictor of the developmental potential of cryopreserved ovarian tissue. In Vivo 20(1): 11-16, 2006. PMID: 16433022.

18 Maltaris T, Dragonas C, Hoffmann I, Mueller A, Beckmann MW and Dittrich R: Simple prediction of the survival of follicles in cryopreserved human ovarian tissue. J Reprod Dev 52(4): $577-$ 582, 2006. PMID: 16799266. DOI: 10.1262/jrd.18012.

19 Duncan FE, Zelinski M, Gunn AH, Pahnke JE, O’Neill CL, Songsasen N, Woodruff RI and Woodruff TK: Ovarian tissue transport to expand access to fertility preservation: From animals to clinical practice. Reproduction (Cambridge, England) 152(6): R201-R210, 2016. PMID: 27492079. DOI: 10.1530/REP-150598

20 Hornick JE, Duncan FE, Shea LD and Woodruff TK: Isolated primate primordial follicles require a rigid physical environment to survive and grow in vitro. Hum Reprod 27(6): 1801-1810, 2012. PMID: 22456922. DOI: 10.1093/humrep/der468

21 Kamoshita K, Okamoto N, Nakajima M, Haino T, Sugimoto K, Okamoto A, Sugishita Y and Suzuki N: Investigation of in vitro parameters and fertility of mouse ovary after storage at an optimal temperature and duration for transportation. Hum Reprod 31(4): 774-781, 2016. PMID: 26908843. DOI: 10.1093/humrep/dew023

22 Gomes RG, Andrade ER, Lisboa LA, Ciquini A, Barreiros TRR, Fonseca NAN and Seneda MM: Effect of holding medium, temperature and time on structural integrity of equine ovarian follicles during the non-breeding season. Theriogenology 78(4): 731-736, 2012. PMID: 22626777. DOI: 10.1016/j.theriogenology. 2012.03.019 
23 Hicks M, Hing A, Gao L, Ryan J and Macdonald PS: Organ preservation. Methods Mol Biol 333: 331-374, 2006. PMID: 16790859. DOI: 10.1385/1-59745-049-9:331

24 Weissman A, Gotlieb L, Colgan T, Jurisicova A, Greenblatt EM and Casper RF: Preliminary experience with subcutaneous human ovarian cortex transplantation in the nod-scid mouse. Biol Reprod 60(6): 1462-1467, 1999. PMID: 10330106. DOI: 10.1095/biolreprod60.6.1462

25 Behnecke A, Mayr S, Schick B, Iro H and Raithel M: Evaluation of ecp release from intact tissue biopsies from patients with nasal polyps. Inflamm Res 57 (Suppl 1): S65-66, 2008. PMID: 18345486. DOI: 10.1007/s00011-007-0632-0

26 Gonçalves RJS, Cavalcante AYP, Gouveia BB, Lins TLB, Barberino RS, Menezes VG, Barros VRP, Macedo TJS Figueiredo JR and Matos MHT: Lower apoptosis rate in ovine preantral follicles from ovaries stored in supplemented preservation media. Zygote 23(6): 943-950, 2015. PMID: 25626913. DOI: $10.1017 /$ S0967199414000665

27 Merdassi G, Mazoyer C, Guerin JF, Saad A, Salle B and Lornage J: Examination of viability and quality of ovarian tissue after cryopreservation using simple laboratory methods in ewe. Reprod Biol Endocrinol 9: 78, 2011. PMID: 21651765. DOI: 10.1186/1477-7827-9-78

28 Laronda MM, Duncan FE, Hornick JE, Xu M, Pahnke JE, Whelan KA, Shea LD and Woodruff TK: Alginate encapsulation supports the growth and differentiation of human primordial follicles within ovarian cortical tissue. J Assist Reprod Genet 31(8): 1013-1028, 2014. PMID: 24845158. DOI: 10.1007/ s10815-014-0252-x

29 Isachenko V, Isachenko E, Mallmann $\mathrm{P}$ and Rahimi G: Increasing follicular and stromal cell proliferation in cryopreserved human ovarian tissue after long-term precooling prior to freezing: In vitro versus chorioallantoic membrane (cam) xenotransplantation. Cell Transplant 22(11): 2053-2061, 2013. PMID: 23127502. DOI: 10.3727/096368912x658827

30 Klocke S, Tappehorn C and Griesinger G: Effects of supra-zero storage on human ovarian cortex prior to vitrification-warming. Reprod Biomed Online 29(2): 251-258, 2014. PMID: 24953192. DOI: $10.1016 /$ j.rbmo.2014.03.025

31 Dittrich R, Lotz L, Keck G, Hoffmann I, Mueller A, Beckmann MW, van der Ven $\mathrm{H}$ and Montag M: Live birth after ovarian tissue autotransplantation following overnight transportation before cryopreservation. Fertil Steril 97(2): 387-390, 2012 PMID: 22177311. DOI: 10.1016/j.fertnstert.2011.11.047
32 Van der Ven H, Liebenthron J, Beckmann M, Toth B, Korell M, Krussel J, Frambach T, Kupka M, Hohl MK, Winkler-Crepaz K, Seitz S, Dogan A, Griesinger G, Haberlin F, Henes M, Schwab $\mathrm{R}$, Sutterlin $\mathrm{M}$, von Wolff $\mathrm{M}$ and Dittrich R: Ninety-five orthotopic transplantations in 74 women of ovarian tissue after cytotoxic treatment in a fertility preservation network: Tissue activity, pregnancy and delivery rates. Hum Reprod 31(9): 20312041, 2016. PMID: 27378768. DOI: 10.1093/humrep/dew165

33 Lan C, Xiao W, Xiao-Hui D, Chun-Yan H and Hong-Ling Y: Tissue culture before transplantation of frozen-thawed human fetal ovarian tissue into immunodeficient mice. Fertil Steril 93(3): 913-919, 2010. PMID: 19108826. DOI: 10.1016/ j.fertnstert.2008.10.020

34 Gastal GD, Alves BG, Alves KA, Souza ME, Vieira AD, Varela AS, Jr., Figueiredo JR, Feugang JM, Lucia T, Jr. and Gastal EL: Ovarian fragment sizes affect viability and morphology of preantral follicles during storage at 4 degrees c. Reproduction 153(5): 577-587, 2017. PMID: 28246309. DOI: 10.1530/rep-160621

35 Gomes RG, Andrade ER, Lisboa LA, Ciquini A, Barreiros TR, Fonseca NA and Seneda MM: Effect of holding medium, temperature and time on structural integrity of equine ovarian follicles during the non-breeding season. Theriogenology 78(4): 731-736, 2012. PMID: 22626777. DOI: 10.1016/j.theriogenology. 2012.03.019

36 Henry L, Fransolet M, Labied S, Blacher S, Masereel MC, Foidart JM, Noel A, Nisolle M and Munaut C: Supplementation of transport and freezing media with anti-apoptotic drugs improves ovarian cortex survival. J Ovarian Res 9: 4, 2016. PMID: 26868273. DOI: 10.1186/s13048-016-0216-0
Received November 24, 2019

Revised December 4, 2019

Accepted December 12, 2019 